\title{
Anthropometric study of facial index of medical students
}

\author{
Pandey N', Gogoi P2, Budathoki D³ ${ }^{3}$ KC G ${ }^{4}$
}

${ }^{1}$ Niraj Pandey, Lecturer; ${ }^{2}$ Parmananda Gogoi, Professor; ${ }^{3}$ Deepesh Budathoki, Lecturer; ${ }^{4}$ Gopal KC, Lecturer; Department of Anatomy, Kathmandu Medical College Teaching Hospital, Kathmandu, Nepal

\begin{abstract}
Background: The human facial contour has always been an interesting subject for anatomists, anthropologists, plastic surgeons and artists. The purpose of study was to create and evaluate data on face anthropometry.

Objectives: To determine total facial index in medical students and to compare these with the data from other population for use in forensic, archaeological studies, anatomy and plastic surgery.

Methods: This is a descriptive study. A total of one hundred and forty medical students, presently studying at Kathmandu Medical College, aged between eighteen and twenty four years were selected as the subjects for the present study. Among the one hundred and forty students, forty four were female and ninety six were male. Two measurements: morphological facial length and bizygomatic breadth were taken by using spreading calibre.

Results: The mean morphological facial length was $110.7 \mathrm{~mm}$ with a standard deviation of $5.98 \mathrm{~mm}$ in males and $102.1 \mathrm{~mm}$ in females. Bizygomatic breadth was $130.8 \mathrm{~mm}$ in males $\& 123.5 \mathrm{~mm}$ in females. The facial index (mean) was 86.09 in males and 84.84 in females.

The dominant type of face shape in males was mesoproscopic (48.66\%) followed by euriprosopic (23\%), leptoprosopic (13.33\%), hypereuriprosopic (13\%) \& hyperleptoprosopic (2\%). In females the dominant type of face was also mesoprosopic (37\%) followed by hypereuriprosopic (22\%), euriprosopic (20.33\%), leptoprosopic (19\%) and hyperleptoprosopic (1.66\%). Conclusion: The dominant phenotype in the studied population was mesoprosopic. The data obtained may be useful in anthropological research, forensic, genetic research, as well as in medical clinical practice.
\end{abstract}

Key words: Anatomy, Anthropometry, Bizygomatic breadth, Facial index, Facial length

\section{INTRODUCTION}

The facial index is the length of the face from the root of the nose to the bottom of the chin, expressed as a percentage of the greatest breadth across the cheek bones. Humans are different by their overall morphology and body dimensions. The human facial contour has always been an interesting subject for anatomists, anthropologists, plastic surgeons and artists ${ }^{1}$. From the human facial form, it is possible to make an absolute distinction between two ethnic groups ${ }^{2}$. Many facial ergonomics deal with anatomical, physiological and psychological characteristics. It is an important area of anthropometry which has become increasingly important in health assessment across many countries $^{3}$. Cephalometry is one of the important parts of anthropometry, in which the dimensions of the head

\section{Address for correspondence}

Dr. Niraj Pandey

Lecturer, Department of Anatomy

Kathmandu Medical College Teaching Hospital

Kathmandu, Nepal

E-mail:drnp77@gmail.com and face are measured ${ }^{4}$. The facial index is the ratio of the morphological facial height to breadth of bizygomatic arch multiplied by 100 . Based on facial index, the types of face shapes can be classified into the following five groups according to Banister's classification ${ }^{5}$ which is tabulated in table 1. Comparison of changes in facial index between parents, offspring and siblings can give a clue to genetic transmission of inherited characters ${ }^{6}$.

\section{METHODS}

A total of one hundred and forty medical students (forty four female and ninety six male), presently studying at Kathmandu Medical College, and aged between eighteen and twenty four years were selected as the subjects for the present study.

The study was carried out at Department of Anatomy, Kathmandu Medical College, Kathmandu, Nepal, from December 2014 to May 2015. A fixed time 11 am to 4 pm was selected for the physical measurement to eliminate the discrepancies due to diurnal variation. The measurements were taken with the help of a spreading 
caliper. Students were informed about the study design, its benefits, privacy of data collected and informed consent was taken. The information regarding the exclusion criteria was collected by eye observation.

Participants with history of oculofacial trauma, craniofacial deformities (congenital or acquired) and abnormal neurological findings affecting the craniofacial dimensions (such as facial palsy, ptosis, and squint) were excluded from the study. Students were asked to sit in a relaxed state, straight and looking forward.

Landmark points used in measuring of the parameters were: nasion-the midpoint of the nasofrontal suture; gnation-in the midline, the lowest point on the lower border of the chin and, zygomatic prominences- the most lateral point on the zygomatic arch.

\section{RESULTS}

The conducted research provides important information concerning the total facial index (TFI), face shape, and facial phenotype in the adult population. The mean values of the morphological facial height and facial breadth were, respectively, $109.61 \mathrm{~mm} \pm 5.98,136.41 \mathrm{~mm}$ \pm 4.85 (Table 3), while the values of the parameters obtained in females, respectively were: $101.34 \mathrm{~mm} \pm$ $6.79,127.59 \mathrm{~mm} \pm 4.90$ (Table 4). It has been shown that males in the studied population have significantly higher values of morphological facial height and facial breadth compared to females.The dominant type of face phenotype in the studied population, according to the value of total facial index was mesoproscopic which was 48.66\% in males and 37\% in females (Table 5).

\section{Table 1:Variables Studied}

\begin{tabular}{ll}
\hline Variables & Definition \\
Morphological facial length & $\begin{array}{l}\text { It is the straight distance from the nasal root (nasion) to the lowest point on the } \\
\text { lower border of the mandible in the mid sagittal plane (gnathion). }\end{array}$ \\
Breadth of the bizygomatic arch & $\begin{array}{l}\text { It is the maximum width of the face extended transversely between the outer } \\
\text { surfaces of the two zygomatic arches. }\end{array}$ \\
\hline
\end{tabular}

Facial index was calculated using the following formula:

Total facial index $=$ nasion- gnathion height $/$ bizygomatic breadth $\mathrm{x} 100$

Table 2: Classification of human face based on facial index

\begin{tabular}{|c|c|}
\hline \multicolumn{2}{|c|}{ Facial index } \\
\hline FI range & Scientific term \\
\hline$<79.9$ & Hyper euriproscopic (very broad face) \\
\hline $80-84.9$ & Euriproscopic (broad face) \\
\hline $85-89.9$ & Mesoproscopic (round face) \\
\hline $90-94.9$ & Leptoproscopic (long face) \\
\hline$>95$ & Hyperleptoproscopic (very long face) \\
\hline
\end{tabular}

Table 3: Descriptive statistics for measurements for Males

\begin{tabular}{lcccccc}
\hline Parameters & Sample size ‘ $\mathbf{N}^{\prime}$ & Minimum & Maximum & \multicolumn{2}{c}{ Mean } & Std. Deviation \\
Facial height-mm & 96 & 94 & 125.0 & 109.61 & 5.98 \\
\hline Bizygomatic facial width-mm & 96 & 123 & 149.0 & 136.41 & 4.85 \\
\hline Valid N (List wise) & 96 & & & & \\
\hline
\end{tabular}

Table 4: Descriptive statistic for measurements for Females

\begin{tabular}{lcccccc}
\hline Parameters & Sample size ' $\mathbf{N}^{\prime}$ & Minimum & Maximum & \multicolumn{2}{c}{ Mean } & \multicolumn{2}{c}{ Std. Deviation } \\
Facial height-mm & 44 & 84 & 116.0 & 101.341 & 6.79 \\
\hline Bizygomatic facial width-mm & 44 & 118 & 144.0 & 127.591 & 4.90 \\
\hline Valid N (List wise) & 44 & & & & \\
\hline
\end{tabular}


Table 5: Classification of students based on total facial index

\begin{tabular}{|c|c|c|c|c|}
\hline \multirow[t]{2}{*}{ Face shape } & \multicolumn{2}{|c|}{ Frequency } & \multicolumn{2}{|c|}{$\%$ Age } \\
\hline & Male & Female & Male & Female \\
\hline Hypereuriproscopic & 12 & 10 & 13 & 22 \\
\hline Euriproscopic & 22 & 9 & 23 & 20.33 \\
\hline Mesoproscopic & 47 & 16 & 48.66 & 37 \\
\hline Leptoproscopic & 13 & 8 & 13.33 & 19 \\
\hline Hyperleptoproscopic & 2 & 1 & 2 & 1.66 \\
\hline
\end{tabular}

\section{DISCUSSION}

In a study by Bhasin MK, Indians showed dominant type of face shape of mesoproscopic which was in correlation with our study ${ }^{6}$. Morphological facial height values obtained in our study $(109.61 \mathrm{~mm} \pm 5.98$, males and $101.34 \mathrm{~mm} \pm 6.79$, females) were lower than the values obtained in the population of northeastern part of Nigeria $(141.15 \mathrm{~mm} \pm 7.5$, males and $141.29 \mathrm{~mm} \pm$ 7.6, females) ${ }^{7}$, the population of India (130.02 $\mathrm{mm} \pm 7.2$, males and $125.4 \mathrm{~mm} \pm 6.0$, females $)^{8}$ and Sri Lanka (140.2 $\mathrm{mm} \pm 10.3$, males and $138.8 \mathrm{~mm} \pm 12.9$, females $)^{9}$.

TFI values obtained in our study were higher in both males and females than the values obtained in the Onge population of India (77.98 male, 75.29 female) ${ }^{10}$ and Japanese adult females 82.66 Hossain et al ${ }^{11}$.The Andhra Region (India) students show bizygomatic distance of males $(\mathrm{mm})$ to be $124.94 \pm 3.85$; females $(\mathrm{mm})$ to be $113.53 \pm 4.56$ and males\& females $(\mathrm{mm})$ to be $119.24 \pm$ 7.10; in our study the values of bizygomatic distance of males $(\mathrm{mm})$ is $136.41 \pm 4.85$; females $(\mathrm{mm})$ is $127.591 \pm 4.90$ and males and females $(\mathrm{mm})$ is $133.643 \pm 6.36^{12}$.

The mean morphological facial height observed in our study $(107.01 \mathrm{~mm} \pm 7.32)$ was lower than the value obtained in a survey conducted among West Africans $(108.4 \mathrm{~mm})^{13}$.The data obtained in our study may be useful in anthropologicalresearch, forensics, genetic research, as well as in medical clinical practice (reconstructive surgery).
In our research, according to the value of TFI, the most common facial phenotype was mesoproscopic, which is consistent with the research results of Pavlica et al. conducted among Montenegrins in Vojvodina (Serbia) ${ }^{14}$.

In a study by Shetti VR et al, 100 ( 66 males \& 34 females) medical students of Kasturba Medical College and MelalaManipal Medical College, Manipal were measured for facial index. The mean facial index for males and females were 87.19 and 86.75 respectively mesoproscopic ${ }^{15}$. In comparison with table 3 and table 4 both measurements were higher in males than in females.

With the help of above statistics, the sex as well as race of the deceased can be determined accurately and this knowledge can be of immense importance.

\section{CONCLUSION}

From our study, we conclude that the dominant facial phenotype in the medical students is mesoproscopic. The data obtained in our study may be useful as a reference for facial analyses that will be further useful in anthropological research, forensics, genetic research,medical clinical practice (reconstructive surgery) and in cosmetology. This study will serve as a basis of comparison for future studies in Nepali population.

\section{REFERENCES}

1. Borman H, Ozgur F, Gursu G. Evaluation of soft tissue morphology of the face in 1050 young adults. Ann.Plast.Surg.1999; 42:280-88.

2. Jahanshahi M, Golalipour MJ, Heidari K. The effect of ethnicity on facial anthropometry in Northern Iran. Singapore Med. 2008; 49(11): 940-3.

3. Ulijaszek SJ, Lourie JA. Anthropometry in health assessment: the importance of measurement error. CollAntropol. 1997; 21: 429-38.

4. Baral $P$, et al. An anthropometry study of facial height among four endogenous communities in the Sunsari district of Nepal. Singapore Med J. 2010; 51(3): 212-5. 
5. Bannister M. Skeletal system. In: Williams PL, et al; Gray's Anatomy. 38th edn. London Churchill Livingstone. 1995; 607-12.

6. Bhasin MK. Genetics of castes and tribes of India: somatometry. Int J Hum Genet. 2006; 6(4): 323-56.

7. Maina MB, et al. Assessments of cranial capacities in a North-Eastern adult Nigerian population. Journal of Applied Sciences. 2011; 11: 2662-5.

8. Gohiya VK, Shrivatava S, Gohiya S. Estimation of cranial capacity in 20-25 year old population of Madhya Pradesh a State of India. Int. J. Morphol. 2010; 28(4): 1211-4.

9. Ilayperuma I. Evaluation of cephalic indices: a clue for racial and sex diversity. Int. J. Morphol. 2011; 29(1): 112-7.

10. Ashok KP. Cephalo-facial variation among Onges. Anthropologist. 2006; 28(4): 245-9.
11. Hossain MG, et al. Change in facial shape in two cohorts of Japanese adult female students twenty years apart. Singapore Med. J. 52(11): 818-23.

12. Vishal M, Salve, et al. A Study of facial (prosopic) index of Andhra Region (India) Students. Novel Science International Journal of Medical Science. 2012; 1(8): 248-52.

13. Herskovits MJ. Physical types of West African Negroes. Hum. Biol. 1937; 9: 483.

14. Pavlica T, Boži-Krsti V, Raki R. Anthropological characteristics of Montenegrins living in Vojvodina. Glasnik Antropološkogduštva Jugoslavije. 2007; 42: 167-77.

15. Shetti VR, et al. Study of prosopic (facial) index of Indian and Malaysian students. Int. J.Morphol. 2011; 29(3): 1018-21. 